\title{
ANALISIS PENGARUH BUDAYA KERJA, JAMINAN SOSIAL DAN LOYALITAS KARYAWAN TERHADAP KINERJA DI PT.GARUDA INDONESIA YOGYAKARTA
}

\author{
Chintya Fitri Yulianti \\ chintyafitri90@gmail.com
}

\begin{abstract}
This study aims: 1) To determine the effect of work culture on employee performance in PT.Garuda Indonesia Yogyakarta. 2) To determine the effect of Social Security on the performance of employees in PT.Garuda Indonesia Yogyakarta. 3) To determine the effect of loyalty to performance employee in PT.Garuda Indonesia Yogyakarta. 4) To determine the effect work culture, social security and loyalty to performance ticketing staff in PT.Garuda Indonesia Yogyakarta. This study used an explanatory research approach to the 80 respondent, employees of the ticketing operation in PT.Garuda Indonesia Yogyakarta. Sampling was done by using census. Data collection techniques in this study using questionnaire. The data obtained were analyzed quantitatively using analytical tool multiple linear regression.Based on the research result, obtained byregression equation is $: Y=0.175 X 1+0.852 X 2+X 30176$. Culture Employment, Social Security and Loyalty affect to performance of the performance ticketing staffin PT.Garuda Indonesia Yogyakarta.
\end{abstract}

Key words: Culture Employment, Social Security, Loyalty, Performance.

\section{Pendahuluan}

\subsection{Latar Belakang}

PT.Garuda Indonesia adalah perusahaan penerbangan milik Negara Indonesia dan menjadi salah satu perusahaan penerbangan terbesar di Indonesia. Perusahaan penerbangan ini mempunyai banyak kantor cabang, salah satunya di kota Yogyakarta yang telah memiliki 16 jadwal penerbangan setiap harinya, yang dimana keberhasilan perusahaan tidak lepas dari sumber daya manusia itu sendiri. Sumber Daya Manusia senantiasa mempunyai kedudukan yang penting dalam sebuah perusahaan, inti dari tujuan para pekerja dalam pekerjaannya adalah mencarikesejahteraan, baik material maupun spiritual. Pembangunan ketenagakerjaan mempunyai banyak dimensi dan keterkaitan.Keterkaitan itu tidak hanya pada kepentingan tenaga kerja selama, sebelum dan sesudah masa kerja tetapi juga keterkaitan dengan kepentingan pengusaha, pemerintah danmasyarakat.
Sumber Daya Manusia memegang peranan yang sangat penting, karena dengan tidak adanya tenaga kerja atau karyawan yang professional dan kompetitif, perusahaan tidak dapat melakukan aktivitasnya secara maksimal meskipun semua peralatan modern yang diperlukan telah tersedia. Melihat sangat pentingnya peranan tenaga kerjasebagai sumber daya manusia dalam proses produksi sehingga diharapkan karyawan akan dapat bekerja lebih produktif dan profesional dengan didorong oleh rasa aman dalam melakukan segala aktivitasnya, perlu diperhatikan ketentuan - ketentuan yang berkenaan dengan keberadaan sumber daya manusia sebagai pekerja dalam perusahaan yang sedikit banyak menentukan tercapai atau tidaknya tujuan perusahaan. Dan salah satu posisi karyawan yang langsung berkaitan dengan pelanggan di PT.Garuda Indonesia adalah staff ticketing, yang dimana proses awal 
pelanggan menggunakan jasa dengan pembuatan tiket dan reservasi. Yang dimana tenaga kerja tersebut memerlukan penghargaan serta diakui keberadaannya, juga prestasi kerja yang mereka ciptakan dan harga diri yang mereka miliki karena sumber daya manusia bukan mesin yang siap pakai. Perusahaan juga harus memberi perhatian yang penuh dan membuat karyawanpercaya terhadap perusahaan, sehingga akan diperoleh komitmen karyawan yang dapat berpengaruh pada loyalitas karyawan pada perusahaan. Jika komitmen karyawan telah diperoleh, akan didapatkan karyawan yang setia dan mampu bekerja dengan sebaik mungkin untuk perusahaan, karena perusahaan mendapat dukungan penuh dari karyawannya sehingga bisa berkonsentrasi secara penuh pada tujuan yang ditujukan, dan yang mempengaruhi atas keberhasilan dari pencapaian perusahaan itu sendiri adalah budaya kerja yang di tentukan oleh perusahaan juga.

Menurut Hadari Nawawi, Budaya Kerja adalah kebiasaan yang dilakukan berulang-ulang oleh pegawai dalam suatu organisasi, pelanggaraan terhadap kebiasaan ini memang tidak ada sangsi tegas, namun dari pelaku organisasi secara moral telah menyepakati bahwa kebiasaan tersebut merupakan kebiasaan yang harus ditaati dalam rangka pelaksanaan pekerjaan untuk mencapai tujuan. Dan, Budaya Kerja adalah suatu falsafah dengan didasari pandangan hidup sebagai nilainilai yang menjadi sifat, kebiasaan dan juga pendorong yang dibudayakan dalam suatu kelompok dan tercermin dalam sikap menjadi perilaku, cita-cita, pendapat, pandangan serta tindakan yang terwujud sebagai kerja (Drs. Gering Supriyadi,MM dan Drs. Tri Guno, LLM ).

Dan, adapun jaminan yang meliputi jaminan yang biasanya sangat diperhatikan adalah jaminan pemeliharaan kesehatan, jaminan kecelakaan kerja, jaminan kematian, jaminan hari tua. Program tunjangan karyawan telah menjadi bagian integral dari sebagian besar paket kompensasi (Henry simamora : 509 ). Terbentuknya loyalitas karyawan dipengaruhi dan terbentuk dari faktor kepuasan karyawan , dan kepuasan kerja karyawan bersifat individual tentang perasaan seseorang terhadap pekerjaannya (Robbins, 1996 ). Maka dari itu pula, loyalitas terbentuk dari kepuasan kerja yang didapatkan dari situasi kerja, ikatan organisasi, keadaan harmonis dan kerjasama antara individu terhadap atasan serta rekan kerja.

Dari pemikiran diatas, maka saya tertarik untuk melakukan penelitian dengan judul Pengaruh Budaya kerja , Jaminan sosial dan loyalitas terhadap kinerja karyawan di PT.Garuda Indonesia Yogyakarta.

\subsection{Landasan Teori}

\subsubsection{Budaya Kerja}

Budaya

kerja

mempengaruhi cara karyawan dalam keterkaitan bekerja antara pegawai, bertingkah laku, dan berkomunikasi. Menurut Hadari Nawawi,Budaya Kerja adalah kebiasaan yang dilakukan berulang-ulang oleh pegawai dalam suatu organisasi, pelanggaraan terhadap kebiasaan ini memang tidak ada sangsi tegas, namun dari pelaku organisasi secara moral telah menyepakati bahwa kebiasaan tersebut merupakan kebiasaan yang harus ditaati dalam rangka pelaksanaan pekerjaan untuk mencapai tujuan.

Menurut Drs. Gering Supriyadi,MM dan Drs. Tri Guno, LLM, Budaya Kerja adalah suatu falsafah dengan didasari pandangan hidup sebagai nilai-nilai yang menjadi sifat, kebiasaan dan juga pendorong yang dibudayakan 
dalam suatu kelompok dan tercermin dalam sikap menjadi perilaku, cita-cita, pendapat, pandangan serta tindakan yang terwujud sebagai tenaga kerja. Yang apabila penerapan budaya kerja yang baik akan berpengaruh pada hasil meningkatnya jiwa gotong royong, kebersamaan, saling terbuka, membangun komunikasi yang lebih baik. Dan budaya kerja yang dimiliki perusahaan juga bertujuan agar terciptanya suatu keseimbangan dan penyampaian perusahaan kepada karyawan supaya selalu dalam jalurnya.

Melihat dari profil PT.Garuda Indonesia itu sendiri telah mempunyai budaya kerja yang dirangkum dalam sebutan FLY-HI yaitu Efficient dan Effective (Cepat, Tepat, Akurat, Hemat), Loyalty (Disiplin, Bekerja Keras dan tuntas), Customer Centricity (Ramah, Hangat, Bersahabat, Tanggap, Proaktif, Kreatif dan Inovatif), Honesty \& Opennes (Jujur, Tulus, Terbuka, Menjaga Kerahasiaan Perusahaan), Integrity (Konsisten dan patuh pada aturan perusahaan).

\subsubsection{Jaminan sosial}

Perkembangan dalam hubungan kerja menunjukkan bahwa imbalan atas prestasi kerja tidak terbatas pada gaji atau upah saja. Lebih dari itu, pekerja juga merasa berhak /atas jaminan sosial yang dipandang sebagai bagian dari sistem imbalan menyeluruh atas peran sertanya di dalam perusahaan.

Menurut

Henry simamora, program tunjangan karyawan telah menjadi bagian integral dari sebagian besar paket kompensasi (2006 : 509). Di dalam UU No.40 tahun 2004 tentang SJSN (Sistem Jaminan Sosial Nasional) ayat 1 menyatakan Jaminan Sosial adalah satu bentuk perlindungan sosial untuk menjamin seluruh rakyat agar dapat memenuhi kebutuhan dasar hidupnya yang layak. Menurut Undang-Undang Republik Indonesia Nomor 3 Tahun 1992 Tentang Jaminan Sosial Tenaga Kerja, jaminan sosial tenaga kerja adalah suatu perlindungan bagi tenaga kerja dalam bentuk santunan berupa uang sebagai pengganti sebagian dari penghasilan yang hilang atau berkurang dan pelayanan sebagai akibat peristiwa atau keadaan yang dialami tenaga kerja berupa kecelakaan kerja, sakit, hamil , bersalin, hamil tua, dan meninggal dunia. Dan dikeluarkan dalam program BPJS meliputi: (1) Jaminan Hari Tua (JHT), (2) Jaminan kecelakaan kerja (JKK), (3) Jaminan Kematian (JK), (4) Jaminan Luar Hubungan Kerja (TK-LHK), dan (5) Jasa Kontruksi.

\subsubsection{Loyalitas}

Kesedian pegawai untuk mempertahankan diri bekerja dalam organisasi adalah hal yang penting dalam menunjang komitmen pegawai terhadap organisasi dimana mereka bekerja. Hal ini dapat diupayakan bila pegawai merasakan adanya keamanan dan kepuasan didalam organisasi tempat ia bergabung untuk bekerja.

Diungkapkan Mowday dan Steers (1979), komitmen merupakan loyalitas karyawan terhadap suatu unit sosial yang bisa berupa loyalitas karyawan terhadap perusahaan, departemen, atau terhadap 
pekerjaan mereka. Menurut Istijanto (2006) karyawan yang tidak setia terhadap perusahaan ditandai dengan perasaan negative, seperti ingin meninggalkan perusahaan, merasa bekerja di perusahaan lain lebih menguntungkan, tidak merasakan manfaat dari perusahaan, dan menyesali keputusan mereka bergabung dengan perusahaan.

\subsubsection{Kinerja}

Kemampuan bertindak dapat diperoleh manusia baik secara alami (ada sejak lahir) atau dipelajari.Walaupun manusia mempunyai potensi untuk berperilaku tertentu tetapi perilaku itu hanya diaktualisasi pada saat-saat tertentu saja.

Menurut Robert L. Mathis dan John H. Jackson (2001: 82) faktor-faktor yang memengaruhi kinerja individu tenaga kerja, yaitu:

Kemampuan mereka,

Motivasi, (3) Dukungan yang diterima, (4) Keberadaan pekerjaan yang mereka lakukan, dan (5) Hubungan mereka dengan organisasi. Berdasarkaan pengertian di atas, penulis menarik kesimpulan bahwa kinerja merupakan kualitas dan kuantitas dari suatu hasil kerja (output) individu maupun kelompok dalam suatu aktivitas tertentu yang diakibatkan oleh kemampuan alami atau kemampuan yang diperoleh dari proses belajar serta keinginan untuk berprestasi.

Menurut Mangkunegara (2000) menyatakan bahwa faktor yang memengaruhi kinerja antara lain: (a) Faktor kemampuan Secara psikologis kemampuan (ability) pegawai terdiri dari kemampuan potensi
(IQ) dan kemampuan realita (pendidikan). Oleh karena itu pegawai perlu dtempatkan pada pekerjaan yang sesuai dengan keahlihannya. (b) Faktor motivasi Motivasi terbentuk dari sikap (atitude) seorang pegawai dalam menghadapi situasi kerja.

Menurut Gibson (1987) ada 3 faktor yang berpengaruh terhadap kinerja: (1) Faktor individu : kemampuan, ketrampilan, latar belakang keluarga, pengalaman kerja, tingkat sosial dan demografi seseorang. (2) Faktor psikologis : persepsi, peran, sikap, kepribadian, motivasi dan kepuasan kerja (3) Faktor organisasi : struktur organisasi, desain pekerjaan, kepemimpinan, sistem penghargaan (reward system). Menurut Kopelman (1988), faktor-faktor yang mempengaruhi kinerja adalah: individual characteristics (karakteristik individual), organizational charasteristic (karakteristik organisasi), dan work characteristics (karakteristik kerja). Lebih lanjut oleh Kopelman dijelaskan bahwa kinerja selain dipengaruhi oleh faktor lingkungan juga sangat tergantung dari karakteristik individu seperti kemampuan, pengetahuan, keterampilan, motivasi, norma dan nilai. Dalam kaitannya dengan konsep kinerja, terlihat bahwa karakteristik individu seperti kepribadian, umur dan jenis kelamin, tingkat pendidikan suku bangsa, keadaan sosial ekonomi, pengalaman terhadap keadaan yang lalu, akan menentukan perilaku kerja dan produktivitas kerja, baik individu maupun organisasi 
sehingga hal tersebut akan menimbulkan kepuasan bagi pelanggan atau pasien. Karakteristik individu selain dipengaruhi oleh lingkungan, juga dipengaruhi oleh: (1) karakteristik orgnisasi seperti reward system, seleksi dan pelatihan, struktur organisasi, visi dan misi organisasi serta kepemimpinan; (2) karakteristik pekerjaan, seperti deskripsi pekerjaan, desain pekerjaan dan jadwal kerja.

Menurut Gomez (dalam Utomo, 2006), dalam melakukan penelitian terhadap kinerja yang berdasarkan perilaku yang spesifik (Judgment performance Evaluation) ini, ada delapan dimensi yang perlu mendapatkan perhatian, yaitu:

1.2.4.1.Quality of work (kualitas kerja)

Kualitas ini akan dicapai berdasarkan syaratsyarat kesesuaian dan kesiapan.

1.2.4.2.Quantity of work (kuantitas kerja)

Jumlah kerja yang dilakukan dalam suatu periode waktu yang ditentukan.

\subsubsection{Job knowledge (pengetahuan pekerjaan) \\ Luasnya pengetahuan mengenai pekerjaan dan ketrampilan.}

\subsubsection{Creativeness}

(Kreatifitas)

Keaslian gagasan-

gagasan yang

dimunculkan dan tindakan-tindakan untuk menyelesaikan persoalan-persoalan yang timbul.
Kesadaran untuk bekerja sama dengan orang lain.

1.2.4.6.Initiative (inisiatif)

Keaslian ide-ide yang disampaikan sebagai program organisasi dimasa yang mendatang.

1.2.4.7.Dependerability

(ketergantungan)

Kesadaran dapat

dipercaya dalam hal

kehadiran dan

penjelassan kerja.

1.2.4.8.Personal

(kualitas personil)

Menyangkut

kepribadian,

kepemimpinan,

kemampuan dan

integritas pribadi.

Bernardin dalam

Novitasari (2003) mengatakan ada enam kriteria yang digunakan untuk mengukur sejauh mana kinerja secara individu, yaitu:

\subsubsection{Kualitas}

Hasil dari aktivitas yang dilakukan mendekati kesempurnaan dalam arti menyelesaikan beberapa cara ideal dan penampilan aktivitas ataupun memenuhi tujuan yang diharapkan dari suatu aktivitas.

\subsubsection{Kuantitas}

Jumlah yang dihasilkan, dinyatakan dalam istilah sejumlah unit, jumlah siklus aktivitas yang diselesaikan.

\subsubsection{Ketepatan waktu}

Dimana tingkat aktivitas yang diselesaikan pada awal yang diinginkan dilihat dari sudut koordinasi yang dengan hasil output serta memaksimalkan waktu 
yang tersedia untuk aktivitas lain.

1.2.4.4.Efektivitas

Tingkat penggunaan sumber daya organisasi dimaksimalkan dengan maksud menghasilkan keuntungan dan mengurangi kerugian setiap penggunaan sumberdaya.

1.2.4.5.Kemandirian

$\begin{array}{lr}\text { Tingkat } & \text { seorang } \\ \text { karyawan } & \text { dapat } \\ \text { melakukan } & \text { fungsi } \\ \text { kerjanya tanpa minta } & \text { mantuan, bimbingan dan } \\ \text { bantuawan } & \text { atau } \\ \text { pengawasan } & \text { turut } \\ \text { meminta ampurnya pengawas. }\end{array}$

1.2.4.6.Komitmen kerja

Tingkat seorang karyawan mempunyai komitmen kerja dengan perusahaan dan tanggung jawab kerja terhadap perusahaan.Ada beberapa aspek yang digunakan untuk mengukur kinerja karyawan yaitu prestasi kerja dan rasa tanggung jawab.

\subsection{Perumusan Masalah}

Permasalahan yang penulis rumuskan dalam penulisan ini adalah sebagai berikut :

1.3.1. Apakah budaya kerja berpengaruh terhadap kinerja karyawan di PT. Garuda Indonesia Yogyakarta?

1.3.2. Apakah jaminan sosial sangat berpengaruh terhadap kerja Karyawan di PT. Garuda Indonesia Yogyakarta?

1.3.3. Apakah loyalitas perusahaan berpengaruh terhadap kinerja karyawan di PT.Garuda Indonesia Yogyakarta?
1.3.4. Apakah budaya kerja , jaminan sosial dan loyalitas secara simultan mempengaruhi kinerja karyawandi PT. Garuda Indonesia Yogyakarta?

\section{Metode Penelitian}

\subsection{Sifat Penelitian}

Penelitian ini menggunakan penelitian kuantitatif dengan tipe penelitian deskriptif yang bermaksud menggambarkan suatu keadaan obyek tertentu yang memiliki suatu hubungan atau pengaruh oleh faktor lain dan penarikan kesimpulannya didasarkan pada angka yang diolah secara statistik.Dimana variabel bebas (independent) yaitu budaya kerja, jaminan sosial dan loyalitas karyawan, sementara untuk variabel terikat (dependent) yaitu kinerja karyawan.

\subsection{Definisi Opersional}

2.2.1. Budaya Kerja (X1)

Budaya kerja mempengaruhi cara karyawan dalam keterkaitan bekerja yang berindikator bertingkah laku, dan berkomunikasi yang dilakukan secara berulangulang, berperilaku, cita-cita, pendapat, pandangan, dan kerja team.

\subsubsection{Jaminan Sosial (X2)}

Jaminan sosial adalah program publik yang memberi perlindungan mendasar bagi tenaga kerja di PT.Garuda Indonesia cabang Yogyakarta untuk mengatasi risiko sosialekonomi yang timbul sehubungan pelaksanaan hubungan kerja yang dimana jaminan sosial itu adalah hak, kebutuhan, meliputiJaminan Hari Tua, Jaminan kecelakaan kerja, Jaminan Kematian, dan lain sebagainya.

2.2.3. Loyalitas (X3) 
Loyalitas karyawan terhadap organisasi memiliki makna kesediaan karyawan untuk melanggengkan hubungannya dengan organisasi, kalau perlu dengan mengorbankan kepentingan pribadinya tanpa mengharapkan apapun, yang meliputi kesetiaan, patuh, berbakti terhadap perusahaan.

\subsection{4. $\operatorname{Kinerja~}(\mathrm{Y})$}

Kinerja yaitu hasil dari kerja karyawan yang diperoleh dalam waktu tertentu, dengan indikator menyelesaikan tugas sesuai target, menyelesaikan tepat waktu, mengurangi kesalahan dan mempunyai inisiatif positif.

\subsection{Populasi dan sampel}

Dalam penelitian ini mengambil populasi karyawan operasional yaitu di bagian tiketing di perusahaan penerbangan PT.Garuda Indonesia cabang Yogyakarta, yang total keseluruhannya adalah 80 orang. Teknik pengambilan sampel dalam penelitian ini adalah sampling jenuh (Sensus), yaitu teknik penentuan sample yang semua anggota populasi digunakan sebagai sample, yaitu 80 karyawan operasional bagian ticketing di PT.Garuda Indonesia Yogyakarta.

\subsection{Sumber Data Dan Metode Pengumpulan} Data

\subsubsection{Sumber Data}

Data yang digunakan dalam penelitian ini adalah data primer, yaitu data yang diperoleh langsung dari obyek penelitian dan data sekunder, yaitu data yang berupa catatan-catatan dan sumber-sumber lain.

2.4.2. Metode Pengumpulan Data

Pengumpulan data dalam penelitian dilakukan dengan metode kuesioner, metode ini digunakan untuk memperoleh data primer, yaitu data yag diperoleh secara langsung dari obyek penelitian melalui angket atau kuesioner dan metode kepustakaan dengan mempelajari buku-buku, literatur-literatur, dokumen-dokumen dan penelitian-penelitian sebelumnya.

\subsection{Teknik Analisis Data}

2.5.1. Uji Validitas

Uji validitas di penelitian ini digunakan untuk mengetahui tingkat keakuratan butir - butir pertanyaan sehingga mempresentasikan variable yang diteliti, item kuesioner dinyatakan valid. Dilakuan dengan membandingkan nilai $r$ hitung dengan $r$ tabel untuk tingkat signifikansi 5 persen dari degree of freedom $(\mathrm{df})=\mathrm{n}-2$, dalam hal ini $\mathrm{n}$ adalah jumlah sampel. Jika $r$ hitung $>r$ tabel maka pertanyaan atau indikator tersebut dinyatakan valid, demikian sebaliknya bila $r$ hitung $<$ r tabel maka pertanyaan atau indikator tersebut dinyatakan tidak valid (Ghozali, 2005).

2.5.2. Uji Reliabilitas

Bertujuan untuk mengetahui sejauh mana suatu alat ukur dapat di percaya atau diandalkan. Dalam pengujian reliabilitas ini menggunakan rumus Alpha, dikatakan reliable jika memberikan nilai Cronbach Alpha $>0.60$.

2.6.Uji Asumsi Klasik

2.6.1. Uji Normalitas

Digunakan

untuk mengetahui apakah populasi data berdistribusi normal atau tidak. Uji ini digunakan untuk mengukur data berskala ordinal, interval, dan rasio. Dan deteksi normalitas dapat dilakukan 
dengan melihat persebaran data pada sumbu diagonal atau grafik normal.

2.6.2. Uji Multikolinieritas

Uji multikolinearitas digunakan untuk mengetahui ada tidaknya hubungan linear antar variabel independen dalam model regresi. Prasyarat yang harus terpenuhi dalam model regresi adalah tidak adanya multikolinearitas. Untuk melakukan uji multikolinearitas dengan cara melihat nilai dari inflation factor (VIF) pada model regresi. Bila nilai VIF lebih kecil dari 10 dan nilai toleransinya diatas 0,1 atau $10 \%$ maka dapat disimpulkan bahwa model regresi tersebut tidak terjadi multikolineritas (Ghozali, 2005).

2.6.3. Uji Heterokedastisitas

Uji heterokedastisitas digunakan untuk mengetahui ada tidaknya ketidaksamaan varian dari residual untuk semua pengamatan pada model regresi. Prasyarat yang harus terpenuhi, bahwa data diasumsikan memiliki varian yang sama dari residual untuk semua pengamatan pada model regresi. Untuk melakukan uji heterokedastisitas, menggunakan uji korelasi Spearman Rho, yaitu mengkorelasikan nilai residual dengan masing-masing variabel independen. Data dinyatakan tidak terjadi heterokedastisitas jika nilai signifikansi lebih besar 0,05 .

2.6.4. Analisis Linear Regresi Berganda

Analisis ini digunakan untuk mengetahui seberapa besar pengaruh variabel bebas yaitu : budaya kerja (X1), jaminan sosial (X2), dan loyalitas (X3) terhadap variabel terikatnya yaitu kinerja karyawan (Y). Persamaan regresi linier berganda adalah sebagai berikut (Ghozali, 2005):

$$
\begin{aligned}
& Y=b 1 X 1+b 2 X 2+ \\
& b 3 X 3
\end{aligned}
$$

Dimana:

Y $\quad$ = Variabel

dependen (kinerja karyawan)

$\mathrm{b} 1, \mathrm{~b} 2, \mathrm{~b} 3=$ Koefisien garis

regresi

$\mathrm{X} 1, \mathrm{X} 2, \mathrm{X} 3=$ Variabel

independen (budaya kerja,

jaminan sosial, loyalitas)

\subsection{Pengujian Hipotesis}

2.7.1. Uji Signifikansi Simultan ( Uji Statistik F )

Pengujian ini dipergunakan untuk menguji pengaruh dari variabel bebas secara bersamasama diuji dengan menggunakan uji F.

Dalam penelitian ini, hipotesis yang digunakan adalah:

Ho : Variabel-variabel bebas yaitu budaya kerja, jaminan sosial dan loyalitas tidak mempunyai pengaruh yang signifikan secara bersama-sama terhadap variabel terikatnya yaitu kinerja karyawan.

Ha : Variabel-variabel bebas yaitu budaya kerja, jaminan sosial dan loyalitas mempunyai pengaruh yang signifikan secara bersama-sama terhadap variabel terikatnya yaitu kinerja karyawan.

2.7.2. Uji Signifikasi Pengaruh Parsial (Uji t)

Uji t digunakan untuk menguji signifikansi hubungan antara variabel $\mathrm{X}$ dan $\mathrm{Y}$, apakah variabel $\mathrm{X} 1, \mathrm{X} 2$, dan $\mathrm{X} 3$ (budaya kerja, jaminan sosial dan loyalitas) berpengaruh terhadap 
variabel Y (kinerja karyawan) secara terpisah atau parsial (Ghozali, 2005). Hipotesis yang digunakan dalam pengujian ini adalah:

Ho: Variabel-variabel bebas (budaya kerja, jaminan sosial dan loyalitas) tidak mempunyai pengaruh yang signifikan t terhadap variabel terikat (kinerja karyawan).

Ha : Variabel-variabel bebas (budaya kerja, jaminan sosial dan loyalitas) mempunyai pengaruh yang signifikan terhadap variabel terikat (kinerja karyawan).

Dasar pengambilan keputusan (Ghozali, 2005) adalah dengan menggunakan angka probabilitas signifikansi, yaitu:

2.7.2.1.Apabila angka probabilitas signifikansi $>$ 0,05 , maka Ho diterima dan Ha ditolak.

\subsubsection{Apabila angka} probabilitas signifikansi < 0,05, maka Ho ditolak dan Ha diterima.

\section{Pembahasan}

3.1.Pengaruh Budaya Kerja terhadap Kinerja

Hasil pengujian hipotesis $\left(\mathrm{H}_{1}\right)$ telah membuktikan terdapat pengaruh antara budaya kerja pada kinerja karyawan operasional PT.Garuda Indonesia Yogyakarta. Melalui hasil dari perhitungan yang telah dilakukan menghasilkan nilai $\mathrm{t}$ hitung sebesar 3,456 dengan taraf signifikasi hasil sebesar 0,001 tersebut lebih kecil dari 0,05 , yang berarti bahwa hipotesis dalam penelitian ini menerima $\mathrm{Ha}$ dan menolak Ho. Pada pengujian ini secara statistic membuktikan bahwa budaya kerja berpengaruh positif terhadap kinerja karyawan operasional PT.Garuda Indonesia Yogyakarta. Hal ini mempunyai arti bahwa ada pengaruh antara variabel budaya kerja terhadap kinerja karyawan karyawan operasional PT.Garuda Indonesia Yogyakarta. Hasil ini mendukung penelitian sebelumnya oleh Risky (2012) yang menyatakan bahwa ada pengaruh positif dan signifikan antara budaya kerja terhadap kinerja karyawan.

3.2.Pengaruh Jaminan Sosial Terhadap Kinerja

Hasil pengujian hipotesis $\left(\mathrm{H}_{2}\right)$ telah membuktikan terdapat pengaruh antara Jaminan sosial terhadap kinerja karyawan operasional PT.Garuda Indonesia Yogyakarta. Melalui hasil perhitungan yang telah diperoleh nilai $t$ hitung sebesar 16.875 dengan taraf signifikasi hasil sebesar 0,000 tersebut lebih kecil dari 0,05 , yang berarti bahwa hipotesis dalam penelitian ini menerima Ha dan menolak Ho. Pada pengujian ini secara statistik membuktikan bahwa jaminan sosial berpengaruh positif terhadap kinerja karyawan operasional PT.Garuda Indonesia Yogyakarta. Hal ini mempunyai arti bahwa ada pengaruh antara variabel jaminan sosial terhadap kinerja karyawan operasional PT.Garuda Indonesia Yogyakarta. Hasil ini mendukung penelitian sebelumnya pada jurnal Vendy Aries, et al (2012) yang menyatakan bahwa ada pengaruh positif dan signifikan antara jaminan sosial terhadap kinerja karyawan.

3.3.Pengaruh Loyalitas Karyawan Terhadap Kinerja

Hasil pengujian hipotesis $\left(\mathrm{H}_{3}\right)$ telah membuktikan terdapat pengaruh antara Loyalitas terhadap kinerja karyawan operasional PT.Garuda Indonesia Yogyakarta. Melalui hasil perhitungan yang telah diperoleh nilai $\mathrm{t}$ hitung sebesar 3,437 dengan taraf signifikasi hasil sebesar 0,001 tersebut lebih kecil dari 0,05 , yang berarti 
bahwa hipotesis dalam penelitian ini menerima Ha dan menolak Ho. Pada pengujian ini secara statistik membuktikan bahwa Loyalitas berpengaruh positif terhadap kinerja karyawan operasional PT.Garuda Indonesia Yogyakarta. Hal ini mempunyai arti bahwa ada pengaruh antara variabel Loyalitas terhadap kinerja karyawan operasional PT.Garuda Indonesia Yogyakarta. Hasil ini mendukung penelitian sebelumnya oleh Bayu wicaksono (2012) yang menyatakan bahwa ada pengaruh positif dan signifikan atara loyalitas karyawan terhadap kinerja karyawan.

\section{Kesimpulan dan Saran}

\subsection{Kesimpulan}

4.1.1. Berdasarkan data yang telah diperoleh dari hasil penyebaran kuesioner, adalah valid dan reliable yang diolah menggunakan pengujian reliabilitas dan validitas, untuk dapat mengetahui jawaban dari pernyataan responden. Dimana alat ukur tersebut dapat diandalkan atau dipercaya dan untuk mengukur sah atau tidaknya kuesioner yang peneliti sebarkan.

4.1.2. Secara simultan variabel Budaya kerja, Jaminan sosial dan Loyalitas berpengaruh terhadap Kinerja karyawan. Artinya setiap perubahan yang terjadi pada variabel Budaya kerja, Jaminan sosial dan Loyalitas akan mempengaruhi atau merubah variabel Kinerja.

4.1.3. Berdasarkan dari perhitungan yang telah dilakukan, diperoleh nilai koefisien sebesar 0,175 dan nilai $\mathrm{t}$ hitung sebesar 3,456 dengan taraf signifikansi hasil sebesar 0,001 tersebut lebih kecil dari 0.05 , yang berarti bahwa hipotesis dalam penelitian ini menerima Ha dan menolak Ho, membuktikan bahwa budaya kerja memiliki pengaruh positif terhadap kinerja karyawan operasional bagian ticketing di PT.Garuda Indonesia Yogyakarta.

4.1.4. Berdasarkan dari perhitungan yang telah dilakukan, diperoleh nilai koefisien sebesar 0,852 dan nilai $\mathrm{t}$ hitung sebesar 16,875 dengan taraf signifikansi hasil sebesar 0,000 tersebut lebih kecil dari 0.05 , yang berarti bahwa hipotesis dalam penelitian ini menerima Ha dan menolak Ho, membuktikan bahwa Jaminan Sosial memiliki pengaruh positif terhadap kinerja karyawan operasional bagian ticketing di PT.Garuda Indonesia Yogyakarta.

4.1.5. Berdasarkan dari perhitungan yang telah dilakukan, diperoleh nilai koefisien sebesar 0,176 dan nilai $\mathrm{t}$ hitung sebesar 3,437 dengan taraf signifikansi hasil sebesar 0,001 tersebut lebih kecil dari 0.05 , yang berarti bahwa hipotesis dalam penelitian ini menerima Ha dan menolak Ho, membuktikan bahwa Loyalitas memiliki pengaruh positif terhadap kinerja karyawan operasional bagian ticketing di PT.Garuda Indonesia Yogyakarta.

4.1.6. Pengaruh yang paling kuat terhadap kinerja karyawan bagian ticketing di PT.Garuda Indonesia Yogyakarta yaitu variabel Jaminan sosial dengan hasil 0.852 .

4.1.7. Untuk loyalitas karyawan dan budaya kerja pun berpengaruh secara imbang pada kinerja karyawan operasional bagian ticketing di PT.Garuda Indonesia Yogyakarta dengan hasil 0,176 dan 0,175 . 
4.2.SARAN

4.2.1. Untuk PT.Garuda Indonesia Yogyakarta

Dari hasil penelitian yang telah berlangsung, Budaya Kerja, Jaminan Sosial dan Loyalitas karyawan di PT.Garuda Indonesia Yogyakarta memiliki peran yang penting agar dapat berlangsungnya kinerja dan hasil yang baik untuk mencapai tujuan perusahaan.

4.2.1.1.Dimana budaya kerja itu sendiri tidaklah lepas dari peran pemimpin yang selalu mendukung, memberikan kepercayaan penuh kepada karyawan dalam melakukan pekerjaan, dan penerapan aturan yang dapat dilaksanakan karyawan dengan baik agar mendapat hasil sesuai dengan tujuan dan harapan perusahaan, namun ada baiknya pemimpin dan karyawan itu sendiri bisa lebih menerima dan berbaur dengan karyawan lainnya agar tidak terciptanya senioritas yang negatif dan harusnya tercipta team yang sangat baik dan kompak dan tetap mempertahankan atau mengembangkan arti nilai dari budaya kerja yang telah di miliki perusahaan yaitu FLY-HI.

4.2.1.2. Untuk tunjangan jaminan sosial, sistem yang telah dilaksanakan oleh perusahaan untuk mengcover karyawannya sudah sangat baik, namun ada baiknya dilakukan pemberian atau pembekalan materi yang terbuka, apa saja yang dapat diterima dengan telah terdaftarnya karyawan di BPJS agar tidak adanya salah faham.

4.2.1.3.Dari segi loyalitas, karyawan bagian ticketing di PT.Garuda Indonesia hampir imbang antara karyawan lama dan karyawan yang tergolong baru dimana harus adanya evaluasi perusahaan untuk mendapatkan kepercayaan dan dukungan karyawan agar selalu loyal dan setia pada perusahaan, contohnya adalah proses jenjang karir atau penghargaan berupa apresiasi kepada karyawan yang dimana bisa memberikan rasa kepedulian dan nyaman untuk selalu setia dan memberikan imbas yang positif bagi perusahaan.

\subsubsection{Bagi peneliti selanjutnya}

Hasil Uji R2 menunjukkan bahwa variabel budaya kerja, jaminan sosial, dan loyalitas karyawan adalah $80,2 \%$. Hal ini menunjukkan bahwa masih ada variabel-variabel lain yang dapat diperhatikan dalam penelitian ini. Penelitian-penelitian lebih lanjut, hendaknya bisa menambah variabel lain yang dapat mempengaruhi kinerja karyawan, karena dengan semakin baik kinerja karyawan maka akan berpengaruh baik juga bagi perusahaan dimana akan cepatnya terwujud dari tujuan perusahaan itu sendiri. 


\section{Daftar Pustaka}

Bernadin dan Russel (1998). Human Resources Management an Experiental Approach. New York : McGraw Hill.

Cascio, W.F. 1992. Managing Human Resources: Productivity, Quality of Work, Life Profits. New York: McGraw-Hill Book Company.

Deewar Mahesa, Djastuti, Indi (2010), Pengaruh Motivasi dan Kepuasan Kerja Terhadap Kinerja Karyawan dengan Lama Kerja sebagai variabel Moderating pada PT.Coca Cola Amatil Indonesia (Central Java). Tesis, Fakultas Ekonomi dan Bisnis, Jurusan Manajemen, Universitas Dipenogoro, Semarang.

Gibson, at al (1996).Perilaku, Struktur, dan Proses, Terjemahan. Jakarta: Erlangga.

http://artikel.iklankecil.com/pengertianoutsourcing-arti-outsourcing.html. Diakses pada tanggal 10 Januari 2014.

http://habibiarifin.blogspot.com/2010/05/bu daya-organisasi-dan-budayakerja.html, diakses pada tanggal 12 Januari pukul 09.15 wib.

http://id.wikipedia.org/wiki/Kinerja, diakses pada tanggal 1 Februari 2013 pukul 08.00 wib.

http://teorionline.net/definisi-konsepbudaya-organisasi/, diakses pada tanggal 5 Februari 2013 pukul 13.10 wib.

Husnan,Suad dan Ranupandojo Heidjrachman,. 1984. Manajemen Personalia, Yogyakarta: Fakultas Ekonomi Universitas Gadjahmada.

Imam Ghozali. 2005. Aplikasi Analisis Multivariate dengan Program SPSS. Semarang: Badan Penerbit Universitas Diponegoro.
Istijanto. 2006. Riset Sumber Daya Manusia. Jakarta: PT. Gramedia Pustaka Utama.

Kopelman, E Richard, at al (1989). The Role of Climate and Culture in Productivity. New Orleans :Tulane University.

Martcahyo, Vendy Aries, et al. 2012. Pengaruh Pelatihan Kerja, Jaminan Sosial dan InsentifTerhadap Kinerja Karyawan Bagian Produksi PT. FumiraSemarang. Skripsi, Fakultas Hukum, Jurusan Ilmu Administrasi Bisnis, Universitas Dipenogoro, Semarang.

Mowday, R., Steers, R., and Porter, L. (1979). The measurement of organizational commitment.Journal of Vocational Behavior, 14, 224-247.

Nawawi, Hadari (2008) ,Manajemen Sumber Daya Manusia : Untuk Bisnis yang Kompetitif. Yogyakarta: Gadjah Mada University Press

Prabu Mangkunegara, A.A. Anwar. 2000. Manajemen Sumber Daya ManusiaPerusahaan. Bandung: Rosda.

Risky. 2012. Pengaruh Komitmen Organisasi, Budaya Kerja Dan Kepuasan Kerja Terhadap Kinerja Karyawan PT.Garuda Indonesia Yogyakarta. Skripsi, Fakultas Ekonomi, Jurusan Manajemen, Universitas Mercu Buana, Yogyakarta.

Robbinss, Stephen. 1996. Organizational Behavior (Terjemahan) Jilid 2. Edisi Ketujuh. Jakarta: PT. Bhuana Ilmu Populer

Robbinss, Stephen. 2003. Perilaku Organisasi, Jakarta: PT. Bhuana Ilmu Populer

Robert, L.Mathis dan John H.Jackson. 2001. Manajemen Sumber Daya Manusia. Jakarta: Salemba Empat 
Sekaran, Uma. 2006, Research Methods for Business: Metodologi Penelitian untuk Bisnis, Edisi 4, Buku 1 dan 2, Penterjemah, Kwan Men Yon. Jakarta: Salemba Empat.

Simamora, Henry, 1995, Manajemen Sumber Daya Manusia. Yogyakarta: STIE YKPN.

Simamora, Henry, 2004, Manajemen Sumber Daya Manusia. Yogyakarta: STIE YKPN.

Simamora, Henry, 2006, Manajemen Sumber Daya Manusia, Edisi III. Yogyakarta: STIE YKPN.

Sugiyono, 2003. Cetakan kelima, Statistika Untuk Penelitian, Bandung:CV Alfabetta.

Sugiyono, 2011.Statistika Untuk Penelitian. Bandung : CV Alfabetta.

Sugiyono.2002. Metode Penelitian Administrasi.Bandung : CV Alfabetta.

Supriyadi, Gering dan Tri Guno, 2007.Arti Definisi/Pengertian Budaya Kerja, diakses pada tanggal 5 Februari 2013 pukul 19.25 wib. http://id.wikimedia.org/wiki/budaya kerja.

UU No.13 Tahun 2003 tentang Ketenagakerjaan.

UU No.40 (2004) tentang SJSN ( Sistem Jaminan Sosial Nasional ).

Wicaksono, Bayu. 2012. Pengaruh Kepuasan Kerja, Loyalitas Karyawan, dan Komitmen Organisasi Terhadap Kinerja Karyawan (kasus pada PT.Vision Land bagian Packing) . Tesis, Fakultas Ekonomi, Program Studi Manajemen, Universitas Stikubank, Semarang. www.garuda-indonesia.com.

Profil

Perusahaan, di akses pada tanggal 5 Februari 2014. 
JURNAL MANAJEMEN VOL 4 NO.2 DESEMBER 2014 